\title{
Burkholderia andropogonis blight of golden cane palms in north Queensland
}

\author{
A. J. Young ${ }^{\mathrm{A}, \mathrm{C}}$, K. R. E. Grice ${ }^{\mathrm{A}}$, P. R. Trevorrow ${ }^{\mathrm{A}}$ and L. L. Vawdrey \\ A Department of Primary Industries \& Fisheries, Centre for Tropical Agriculture, 28 Peters Street, Mareeba 4880, \\ Queensland, Australia. \\ ${ }^{B}$ Department of Primary Industries \& Fisheries, South Johnstone Research Station, South Johnstone Road, \\ South Johnstone 4859, Queensland, Australia. \\ ${ }^{\mathrm{C} C}$ Corresponding author. Email: anthony.young@dpi.qld.gov.au
}

\begin{abstract}
Nursery-grown golden cane palms (Dypsis lutescens) in north-eastern Queensland exhibited angular, watersoaked and chlorotic haloed lesions typical of blight symptoms. Bacteria isolated from oozing preparations were identified as Burkholderia andropogonis through culture characteristics, microscopy, biochemical activity and 16S rRNA gene sequencing. A healthy golden cane palm was inoculated with the isolate and external symptoms were reproduced after approximately three months, whereupon the pathogen was reisolated.
\end{abstract}

The golden cane palm (Dypsis lutescens) is a popular indoor and outdoor ornamental plant in Australia. In March 2006, a blighted golden cane palm leaf was received at the Centre for Tropical Agriculture in Mareeba, north Queensland, Australia. Affected leaves had 1-5 cm longitudinal angular, necrotic, water-soaked lesions with chlorotic margins (Fig. 1). Advanced lesions would fuse and result in the withering of the whole frond. Bacterial ooze was observed when transverse sections were examined with a compound microscope (Fig. 2). Subsequent inspection of the nursery revealed several densely packed plant bays of golden cane palms to be severely affected. The grower stated that the problem was first noticed during the previous wet season but was not reported because the incidence and severity of symptoms had lessened during the subsequent dry season.

In the laboratory, infected material was rinsed in tap water, then distilled water, then surface-sterilised by spraying with $70 \%$ ethanol, wiped clean with lint-free tissue, then sprayed with $70 \%$ ethanol until saturated. Once dry, lesions were sectioned transversely using sterile forceps and a razor and the exposed tissue was streaked directly onto casamino acid-peptone-glucose (CPG) media (Kelman 1954). The presence of bacteria in the sample was confirmed by subsequent microscopic observation of bacterial ooze in the isolation material. Other sections of lesions were placed in a Petri dish and overlaid with $1 \mathrm{~mL}$ of sterile water. After $20 \mathrm{~min}$, a loop of elution was streaked onto CPG. The tissue was then crushed with a sterile glass rod and another loop of elution was streaked onto CPG. Plates were incubated at $28^{\circ} \mathrm{C}$ and bacterial growth was observed after $48 \mathrm{~h}$.

All three preparations yielded identical bacterial colonies after $48 \mathrm{~h}$. These were small $(0.5-1 \mathrm{~mm})$, round, entire, slightly raised, white, catalase positive and negative for oxidase and potato soft rot tests. The bacteria were slightly curved Gram negative rods $(0.4 \mu \mathrm{m} \times 1.5-2.0 \mu \mathrm{m})$, motile via $1-2$ polar flagellae. No colony growth was observed at $40^{\circ} \mathrm{C}$.
A representative of the isolates, designated CTA12944, has been lodged at the Australian Collection of Microorganisms (accession ACM5245).

Pathogenicity was demonstrated by stab inoculation of the youngest fully expanded frond of a healthy golden cane palm with a pure bacterial suspension $\left(\sim 10^{7}-10^{8} \mathrm{cfu} / \mathrm{mL}, \mathrm{A}_{540}=0.5\right)$. Another portion of the frond was used as a control which was stab-inoculated using pure water. The inoculated fronds were covered with a plastic bag to create an incubation chamber, which was removed after $48 \mathrm{~h}$. The plant was maintained in the glasshouse and symptom development was observed on a weekly basis. After three months a lesion similar to that observed in the nursery plants had developed (Fig. 3). No symptoms developed in the control. Bacterial ooze was observed microscopically in the sectioned lesion and the inoculated bacterium was reisolated.

The 16S rDNA was amplified using the primer set F27 and R1492 (Lane 1991), yielding a 1500-bp product which was cleaned by ethanol precipitation and washing in $70 \%$ ethanol. The fragment was cloned into the pGEM T-Easy vector (Promega) and transformed into JM109 cells according to the manufacturer's instructions. Column (QIAGEN) purified plasmids from positive colonies were used as template for forward and reverse sequencing reactions which were separated using an ABI automated sequencer. Raw data were edited using FinchTV software.

Edited sequences were compared with other sequences using the internet-based program BLAST. The 693 bases of the forward partial 16S rDNA sequence (GenBank accession EU075174) shared $>99 \%$ homology $(692 / 693)$ to a Florida strain of $B$. andropogonis strain 6369 , differing in a single thymine-cytosine substitution, while 296 bases of the reverse partial 16S rDNA sequence (GenBank accession EU075175) were $>99 \%(296 / 297)$ to B. andropogonis strain 6269 from Florida, differing only in a single guanidine deletion. The 


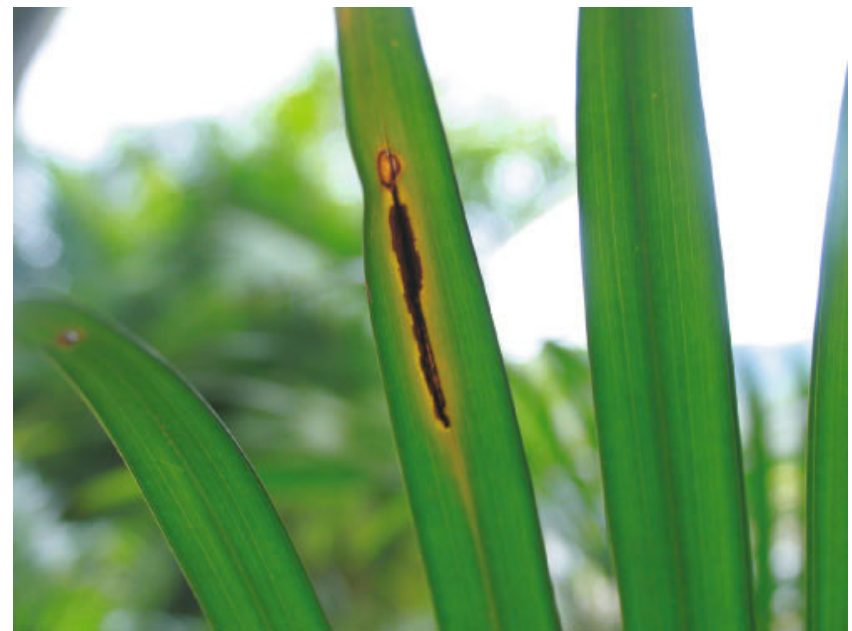

Fig. 1. Typical angular necrotic lesion in the field.

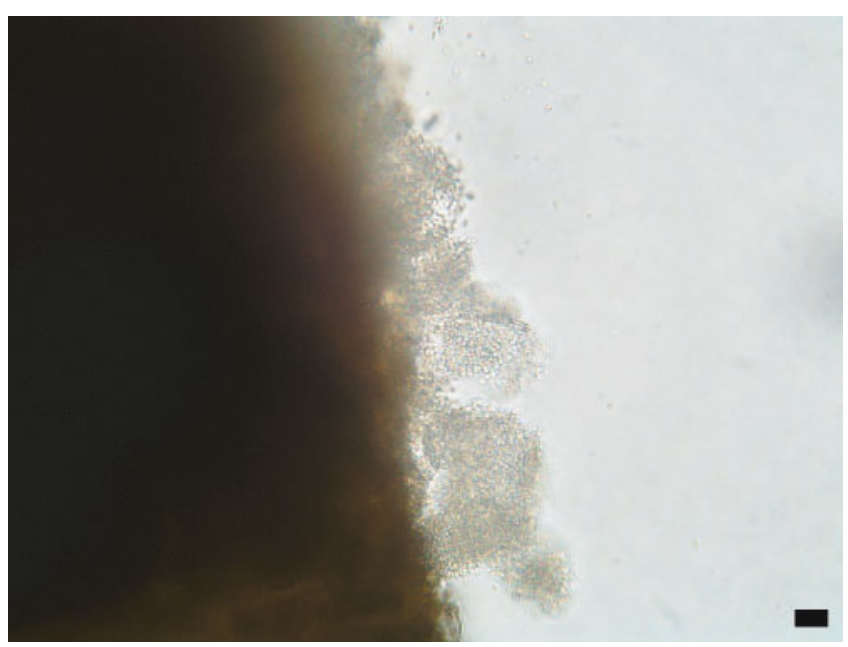

Fig. 2. Bacterial oozing from cut lesion (bar represents $10 \mu \mathrm{m}$ ).

BIOLOG $^{\mathrm{TM}}$ assay was also performed and gave a highest match (0.612) to B. andropogonis.

Burkholderia andropogonis (Smith) is broadly distributed geographically and has an extensive host range. It is known to primarily infect members of Poaceae and Fabaceae, where it causes the greatest disturbance to agriculture, but it has also been found to naturally infect many other plant families (Bradbury 1986). This is the first report of $B$. andropogonis infection of a member of the Arecaceae. The disease appears strikingly similar

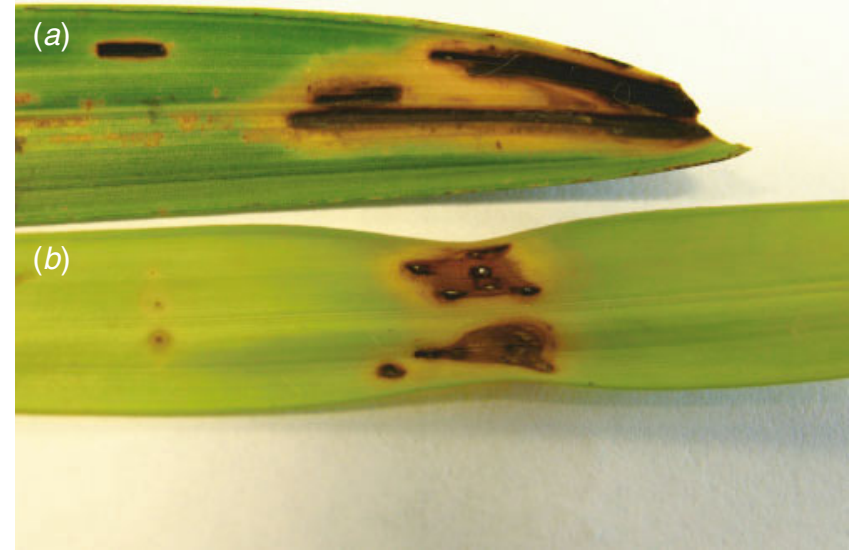

Fig. 3. (a) Naturally infected and (b) inoculated golden cane palm fronds.

to one described on fishtail palms in Florida (Knauss et al. 1978; Miller 1992), reported to be caused by the closely related Acidovorax avenae subsp. avenae.

Being a bacterial pathogen with presumed water spatter transmission, immediate management recommendations included removal of infected foliage and severely infected plants, greater spatial separation and regular applications of copper fungicides. An inspection during the subsequent wet season revealed reduced levels of infection and severity in the plants.

\section{References}

Bradbury JF (1986) 'Guide to plant pathogenic bacteria.' (CAB International Mycological Institute: Egham, UK)

Kelman A (1954) The relationship of pathogenicity in Pseudomonas solanacearum to colony appearance on the tetrazolium medium. Phytopathology 39, 936-946.

Knauss JF, Miller JW, Virgona RJ (1978) Bacterial blight of fishtail palm, a new disease. Proceedings of the Florida State Horticultural Society 91, 245-247.

Lane DJ (1991) 16S/23S rRNA sequencing. In 'Nucleic acid technologies in bacterial systematics'. (Eds E Stackebrandt, M Goodfellow) pp. 115-117. (John Wiley and Sons Ltd: London)

Miller JW (1992) Bacterial blight of fishtail palm caused by Pseudomonas avenae. Plant Pathology Circular No. 355. Florida Department of Agriculture and Consumer Service Division of Plant Industry.

Manuscript received 11 July 2007, accepted 13 August 2007 